\title{
21. Yüzyılda Yeni Nesil Konaklama Yapıları: Butik Otel Yaklaşımı
}

\author{
21st Century New Generation Accomodation Buildings: Approach of Boutique Hotel
}

\section{Ece AYKOL*, Rengin ZENGEL**}

* Yüksek Lisans Öğrencisi, Dokuz Eylül Üniversitesi, Fen Bilimleri Enstitüsü, Mimarlık Bina Bilgisi ABD, 35160 Kaynaklar Yerleşkesi, Tınaztepe, Buca, İzmir. E-posta: ece-aykol@hotmail.com

**Doç. Dr., Dokuz Eylül Üniversitesi, Mimarlık Fakültesi, Mimarlık Bina Bilgisi ABD, 35160, Kaynaklar Yerleşkesi, Tinaztepe, Buca, İzmir. E-posta: renginzengel@gmail.com

\section{MAKALE BILGILERI}

Makale ișlem bilgileri:

Gönderilme tarihi: 5 A ğustos 2013

Birinci değerlendirme: 13 Aralık 2013

İkinci değerlendirme: 12 Mart 2014

Kabul: 14 Mart 2014

\section{Anahtar sözcükler:}

Konaklama yapıları,

Turizm,

Butik otel,

Aidiyet, Deneyim.

\section{ARTICLE INFO}

Article history:

Submitted: 5 August 2013

Resubmitted: 13 December 2013

Resubmitted: 12 March 2014

Accepted: 14 March 2014

Key words:

Accomodation buildings,

Tourism,

Boutique hotel,

Sense of belonging, Experience.

\section{ÖZ}

Bu çalıșma, gelișen ve değișen yaşam şartları ile birlikte oluşan yersizlik kavramı, butik oteller üzerine alanyazındaki yetersiz tanımlamalar ve dolayısıyla bunların sonucunda tasarlanan niteliksiz konaklama yapıları olarak üç sorun üzerinden ele alınmıştır. Öncelikli olarak butik kavramına temellenen anlayışın farklı süreçlerde, farklı disiplinlerde hangi bağlamlar üzerinden kurgulandığı tartışlarak butik otel tanımlamalarına açıklık getirilmeye çalışılmıştır. Bu çerçevede gerek yurtdışı gerekse Türkiye'deki birçok otel tasarım ve işletmeciliğinde idealde bir butik otelin barındırması gereken özelliklerden yalnızca birkaçına sahip olan konaklama yapılarının butik otel olarak adlandırılması, önemli bir kavramsal tutarsızlık olarak gösterilebilir. Ayrıca yurtdısında sıklıkla rastlanılan farklı butik otel tipolojilerine Türkiye'de de yer verilmeye bașlanmasına rağmen bu otellerin tanımlamalarına henüz alanyazında yer verilmediği görülmüştür. Turizm ve mimarlık ara kesitinde yer alan bu çalışmada getirilen yeni tanımlamalar göz önünde bulundurularak bu yapıların barındırması gereken özelliklerin netleștirilmesi, dolayısıyla turizm sektöründeki yanlıs tanıtımlara engel olunup kullanıcıların bilinçli tercih yapmasını sağlamak bu çalıșmanın öncelikli hedeflerindedir. Bu çalışmanın sonucunda işletmecilerin ve kullanıcıların tutarlı tanımlamalar ile butik otel yaklaşımını benimsemesi ve doğru tercihler yapması beklenmektedir. Ayrıca netleştirilen tanımlamalar ile konaklama tesislerinin butik otel sınıflandırmasına dâhil olup olmadıkları daha tutarlı bir şekilde tespit edilebilecektir.

\section{Giriş}

Üç tarafı denizlerle çevrili Türkiye'nin gelişiminde her geçen gün daha fazla önemli bir konuma sahip olan turizm ve bu alana ayrilan yatırımlar, tasarlanan konaklama yapılarının mekânsal ölçek-

* Bu makale Ece Aykol'un, İzmir Dokuz Eylül Üniversitesi Fen Bilimleri Enstitüsü Mimarlık Bina Bilgisi Programında yazılan "Butik Otellerde Mekân Çözümleri ve Tasarımsal Yaklaşımlar" başlıklı Yüksek Lisans tezinden derlenmiştir. te kullanıcılarına sunduğu kalite ve hizmet anlayışını da bir o kadar değerli hale getirmektedir. Son yıllarda popüler bir yatırım aracı olarak var edilen butik otel kavramı, konaklama yapıları arasında, içeriği tasarlandığı coğrafyaya göre farklılık gösterebilen belirsiz bir tanımlama içinde var edilmektedir. Anlayış olarak turizm ve mimarlık disiplinleri arasında kalan butik otelin, işletme yaklaşımı ve mekânsal açıdan tam olarak hedeflenen ölçütlerinin net bir șekilde belirlenmesi önemli bir gerek- 
liliktir. Tanımlamalardaki belirsizlikler nedeni ile suiistimal edilen butik otel yaklaşımı, turizm aç1sindan negatif bir imaj sergilemekle birlikte kullanıcısını da kandırmaktadır. Bu çerçevede adını her alanda sıklıkla duyduğumuz butik kavramının, işletme anlayışı ve mekânsal özelliklerinin konaklama yapıları üzerinden irdelenmesi araştırmanın çıkış noktasını oluşturmaktadır.

Araştırma, temel olarak üç sorun üzerine kurulmuştur. Bunlardan ilki; değişen ve gelişen yaşam koşulları sebebi ile kişilerin boş zamanlarının yetersizliği ve bunun sonucunda az zaman geçirdikleri ev konforuna, ev hissiyatına duyulan özlemdir. $\mathrm{Bu}$ duruma alternatif olarak sunulan ve günümüzde giderek popülerleşen, adına birden çok alanda rastlanılan butik yaklaşımı ise butik oteller özelinde değerlendirilecektir. Butik otellerin hizmet anlayışının ve mekân niteliklerinin net bir tanımlamaya sahip olmayışı ve bununla birlikte kendi içlerinde yine çelişkili tanımlarla gruplara ayrılması ikincil sorun olarak ele alınmaktadır. Üçüncü sorun ise tanımlamalardaki belirsizliğin etkisi ile butik otel anlayışını benimsememiş fakat butik otel olarak adlandırılan kimliksiz konaklama yapılarının ortaya çıkmasıdır. Çalışmada amaçlanan, butik anlayışını hizmet ve mekânsal olarak, turizm ve mimarlık disiplinleri beraberinde ele alıp çelişkisiz tanımlamalar ortaya koyarak hem otel işletmecilerine hem de otel kullanıcılarına bir kaynak oluşturmaktır.

Turizm anlayışı ve dolayısıyla konaklama yapıları değişen yaşam tarzı ile paralel olarak gelişmektedir. İnceoğlu ve İnceoğlu'nun (2013) belirttiği gibi 19. yüzyılda demiryollarının yaygınlaşması ile birlikte han ve kervansaraylar yerini kent otellerine bırakırken, 20. yüzyılda yıldızlı oteller ve tatil köyleri ortaya çıkmaktadır. Bu süreçler boyunca da seyahat edenlerin konfor beklentileri sürekli artmış ve artık amaç seyahat edenlerin otelden beklentilerini en üst düzeyde karşılamak haline gelmiştir. Aytaça (2006) göre yaşam, geçmişe oranla daha değişken, daha mobil ve daha plastik bir boyuttadır. Yaşam ve kimlik ölçütleri kayganlaşırken değişkenlik, yersiz yurtsuzluk, mobillik insanları günden güne etkisi altına almaktadır. Günümüzde artan hareketlilik durumu nedeni ile Tanyeli'nin de (2013) belirttiği gibi otel, modern çağda neredeyse konutun tek alternatifi olmaktadır. Hatta sürekli otelde yaşayanlar bile bulunmaktadır. Otellerde geçirilen zamanların artması nedeniyle de kullanı- cıların otellerde ev hissiyatını talep etmesi kaçınılmazdır. Douglas'a (1991) göre ev, sabit bir yere konumlanmış olmak zorunda değildir. Bir karavan, bir çadır, bir bot eviniz olabilir. Kendi kontrolünüz altına alabildiğiniz mekân, evinizdir. Bu yaklaşıma göre de konaklama yapılarında geçirilen zamanın artması, otelleri kendi evimize çevirme yani kontrolümüz altında bulundurmak isteme anlayışını pekiştirmektedir. Yıldızlı oteller belirli standartları nedeni ile bu isteğe yanıt veremez iken butik oteller bu durumda iyi bir alternatif olarak ön plana çımaktadır.

Turizm Tesislerinin Belgelendirilmesine ve Niteliklerine İlişkin Yönetmelik'in 43. maddesinde tanımlanan butik otel ölçütleri ele alındığında, bu özelliklerin birçok butik otelde sağlanmadığı görülmektedir. Butik anlayışı kavramsal olarak eşsiz, tek olmayı gerektirirken birçok butik otel örneği bu duruma tamamıla zıt olan zincir otel anlayışı içinde işletilmektedir. Yanı sıra genel olarak lüks, konforlu ve pahalı olarak bilinen butik otellerde kimi zaman deneyim sağlamak uğruna konfordan ve lüksten ödün verildiği durumlara da rastlanmaktadır. Bu nedenle de tatil köylerinde sıkça rastladığımız temalı tasarımlara gidilmekte ve yine butik anlayışına zıt, sahneleşmiş mekân örnekleriyle karşılaşılmaktadır. Elçin'e (2007) göre başka "şeylere", başka "zamanlara" ait bileşenlerin bir araya gelmesi ile oluşturulan kurgu mekânların, "köy gibi" "saray gibi" "ev gibi" belirlenmiş suni imajlar çerçevesinde geliştirilerek insanların fantezilerine yanıt vermesi beklenmektedir. Tatil köylerindeki suni imaj yaklaşımı ile "ev gibi" olma, evinde gibi hissettirme yaklaşımı da aynı imaj olgusu kapsamında değerlendirilmektedir. Bu yaklaşımlar, butik otellerin zaman zaman kendi içlerinde çelişkili duruma düştüklerinin göstergesidir.

\section{KURAM}

Yaşam şartları ve beklentilerin değişkenlik göstermesi üzerine bir alternatif olarak sunulan butik kavramı, bu çalışmanın temelini oluşturmaktadır. Çalışmada ilk olarak butik kavramına ve farklı disiplinlerdeki tanımına değinilecek, daha sonra örnekleri giderek artan butik otel tipolojilerine açıklık getirilecek ve son olarak da belirlenen butik otel tanımlamaları ile çelişen örneklere de yer verilecek, olumlu ve olumsuz örnekler değerlendirilerek kullanıcıya bu otellerin barındırması gereken özellik- 


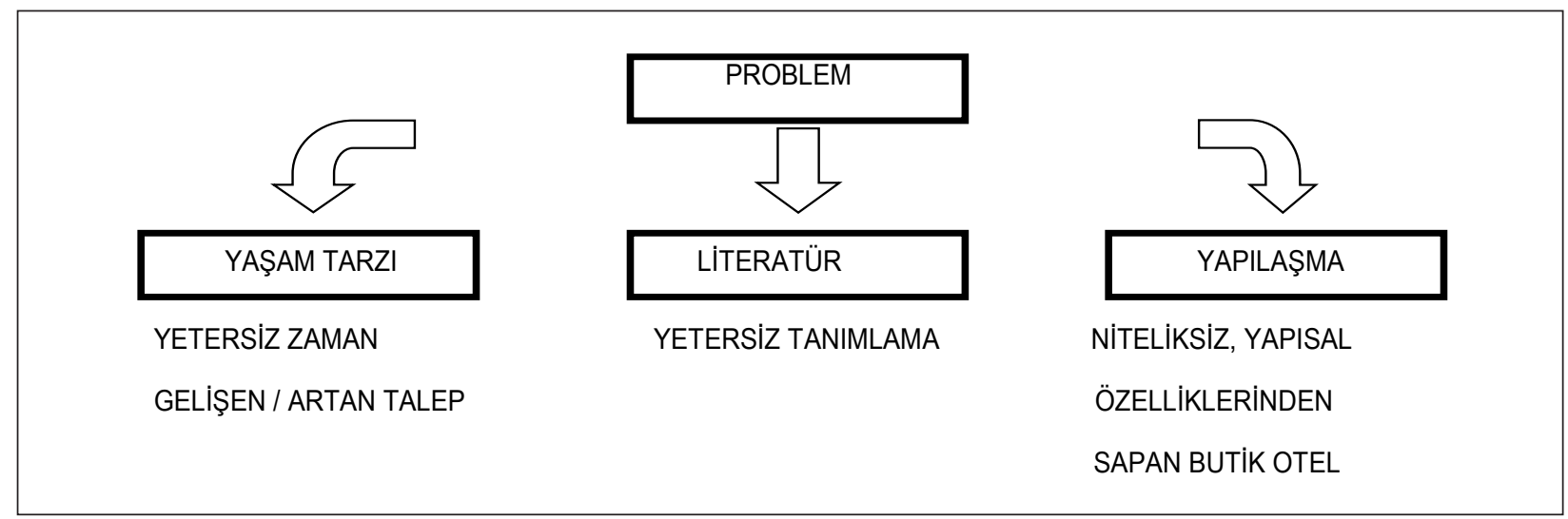

Kaynak: Aykol 2013.

ler aktarılacaktır. Araştırma, temel olarak üç problem üzerine kurulmuştur(Bkz. Tablo 1).

İlk problem olarak belirlenen yaşam tarzının değişkenliğe uğraması, konaklama yapılarında da farklı yaklaşımlara gidilmesinde etkili olmaktadır. Beneton'1n da (1991) bahsettiği üzere; kapitalist çalışma yaşamının biçimsel, kuralcı zihniyeti insanları, çalışma hayatından arta kalan zamanlarını programlamaya itmektedir. Yenal'a (2013) göre ise boş zaman hızlanan iş temposuna eklemlenmekte ve mesaileşmektedir. Günümüzde insanlar çalışma saatleri dişındaki vakitlerinde hem görünür olmak hem de hizmetin en kalitelisini almak istemektedir. Bu nedenle de hem tasarım hem de hizmet sektöründe beklentiler giderek artmaktadır.

Gündelik hayatın hızlı ve monoton temposunda planlanıp programlanan tatil süreçleri de aynı zamanda statü gösterişi için bir fırsat haline gelmektedir. Altun-Doğaner'e (2005) göre de günümüz post-modern anlayışı ve bunun sonucunda ortaya çıkan tüketim kültürü herkese sonsuz özgürlük sunmakta ve her isteği mümkün hale getirmektedir. Harvey'e (1997) göre tüketim sadece giyim, dekorasyon gibi tasarım alanlarında değil, hizmet anlayışı, dinlenme faaliyetleri gibi alanlarda da etkili olmaktadır. Turizm sektörü de kullanıcıların değişen isteklerine ayak uydurmak zorunda kalmaktadır. Altun (2013), konaklama yapılarındaki değişkenliği, otelin işlevinden çok, tüketicinin yaşam tarzı, boş zamanını nasıl geçirmek istediği ve buna bağlı olarak farklılaşan beklentileridir, sözleriyle özetlemektedir.
Yukarıda anlatılanların sonucunda konaklama yapılarında da alternatif arayışlar meydana gelmektedir. Altun'a (2013) göre, değişen ihtiyaçların paralelinde gelişen konaklama yapıları tatil köyleri, iş otelleri, spa otelleri, temalı oteller, butik oteller, tasarım otelleri (design hotels), sanat otelleri (art hotels), HIP oteller gibi farklı tasarım ve hizmet anlayışlarına göre sınıflandırılmaktadır. Bu otel yaklaşımlarında günümüz kullanıcısına hizmet, konfor ve imaj kavramlarının bütününü sunan alternatif ise butik oteller olmaktadır. Küçük ölçekli ve özgün tasarımları, kişiye özel hizmet anlayışı, kullanıcısına ev konforunu ve sıcaklığını yaşatma, deneyim sunma gibi birçok özelliği açısından, evinde kısıtlı zaman geçiren, boş zamanlarını planlayan günümüz kullanıcısı için risksiz bir konaklama alternatifi olmaktadır. Yenal'a (2013) göre de büyük kentlerde yaşayan, eğitimli, kariyer sahibi, zengin orta sınıflar için kitle turizminin bildik pratikleri cazibesini yitirmektedir ve turizmin paketlenmiş standart tatil anlayışı yerine butik otel yaklaşımları ön plana çıkmaktadır.

İkincil problem olarak ele alınan, günümüzde giderek isimlerine daha sık rastladığımız tasarım otelleri, HIP oteller olarak yurtdışında anılan fakat Türkiye'de henüz yer etmeyen butik otel yaklaşımlarıdır ve çalışmada bu yeni nesil otellere tanımlamalar getirilecektir. Pehlivanoğlu'na (2010) göre de son beş yıl içerisinde turizm ve otelcilik alanyazınına girmeye başlayan ancak resmileşmemiş HIP Otel kavramı alternatif oteller sinıflandırmasında gösterilmektedir. Bu sinıflandırmalara Türkiye'de henüz yer verilmeyişi araştırmanın bu alana yönel- 
mesini sağlamıştır. Yetersiz tanımlamalar ve dolayısı ile kullanıcının yeterli bilgiye sahip olmaması fırsat bilinerek, az sayıda oda kapasitesine sahip olan birçok konaklama yapısı butik otel olarak adlandırılmakta, bunun üzerinden getirim sağlanmaktadır. Bu durumun sonucunda da 21. yy. yaşam tarzına iyi bir alternatif olan ve rağbet gören nitelikli konaklama yapıları kullanıcısına yanlış tanitilmaktadir.

Yetersiz alanyazın tanımlarının da etkisi ile ortaya çıkan niteliksiz konaklama yapıları da üçüncül problem olarak ele alınmıştır. Tanımlara bakıldığında özgünlük özelliğinden kaynaklı olarak belirli standartlara sığdırılamayan butik otellere net bir tanımlama getirilememektedir. Belirlenen özelliklerin ucu açık kalmaktadır. Özgün olması, tefrişinde antika veya tasarım ürünler kullanılması, küçük ölçekli olması, farklı deneyimler sunması, kullanıcısına ev konforunu yaşatması ve zincir otel olmaması butik otellerin barındırması gereken özelliklerdir. Bu özelliklerden de anlaşılacağ 1 üzere belirli bir standartlaşma görülmemektedir. Özüne bakıldığında, kalıplaşmış standartlar butik otellerin mantığı ile örtüşmemektedir. Öyle ki küçük ölçekli olması gereken butik otellerin oda sayıları dahi farklı ülkelere göre değişkenlikler gösterebilmektedir. Freund deKlumbis (2004) butik otellerin oda sayısını 50 ve 100 olarak belirtirken Caterer Search (2005) 50 odadan az, Erkutlu ve Chafra (2006) 3 ve 100 oda, Henderson (2011) ise en fazla 100 oda, McDonnel Covelli (2005) ise en fazla 150 oda olarak tanımlamıştır. Türkiye'de Turizm Tesislerinin Belgelendirilmesine ve Niteliklerine İlişki Yönetmeliğin 43. maddesinde ise 10 ile 60 oda aralığında olması gerektiği belirtilmiştir. En belirleyici özellik olan oda sayısında bile bölgelere göre tutarsızlıklar gözlemlenmektedir ve bu özellikte dahi nitelikler standartlaşamazken özgün olma, farklı deneyim sunma, kişiye özel hizmet anlayışı gibi ucu açı kalan özelliklerin değişkenlik göstermesi şaşırtıcı değildir. Bu tanımlara karşı olarak Rowe (2003), butik otellerin küçük olmasının önemli bir özellik olduğunu vurgulamıştır. Rowe, bunun kişiye özel hizmet ve samimi bir ortam yaratmak ad1na bir gereklilik olduğunu savunurken, Schrager Otelleri'nin kurucusu olan Ian Schrager ise butiğin bir yaklaşım ve tutum olduğunu otel büyüklüğü ile değerlendirilmemesi gerektiğini (Wheeler 2006) savunmuştur. Kendi otellerinde de çok sayıda oda kapasitesi barındırıp müşterilerine teatral atmosfer içinde mimari, tasarım, renk, ş̧ık gibi farklı duyuların algıladığı deneyimler sağlamaktadır. Bu yorumlamalar nedeniyle tanımlamalar ile çelişen örneklere rastlanmaktadır. Zincir otel anlayışına hem işletme hem de mekânsal yaklaşım olarak zıt olan butik otellerin zincirleşmiş örnekleri türemeye başlamaktadır. Örneğin temalı tatil köylerine karşı bir yaklaşım olan butik otellerde de artık tema$l_{1}$ otel örneklerine rastlanılmaktadır. Deneyim adı altında hapishane otel, arena otel, okul otel olarak mekânların otel işlevlerine dönüştürüldüğü örnekleri mevcuttur. Farklı deneyimleri sunmak adına temalaştırılan bu örnekler ile birlikte, "ileride butik otellerin de eleştirilen sahte kimlikli tatil köyü yapılarına dönüşmesi kaçınılmaz mı olacaktır?" sorusu akillara gelmektedir.

\section{ILGILI ÇALIŞMALAR}

Olga'nın (2009) aktarımıla butik otelin ilk örneği, zincir otellerin standartlığına karşı bir yaklaşım olarak, 1981 yılında hizmete sunulan, ünlü tasarımc1 Anouska Hempel tarafindan tasarlanan, Londra'daki Blakes in London otelidir. Butik yaklaşımı hızla yayılmış yine 1981 yılında San Francisco'da Clarion Bedford oteli açılmıştır. Ian Schrager ise ikonik butik otelleri ile bu sektöre 1984 yılında New York'taki Morgans Hotel ile dâhil olmuştur. Bu örneklerin sonrasında butik otel yaklaşımı günden güne gelişmiş ve birçok ülkede sayıları hızla artış göstermiştir. Her bir örneğinde fiziksel ve işletme anlayışı olarak farklı niteliklere sahip olan butik otellerin tanımlamalarını butik otel yöneticilerinin, tasarımcilarının ve otel sahiplerinin hemfikir olduğu özellikleri Anhar (2001); mimari ve tasarım, hizmet, hedef kitle, konum (şehir merkezi ve tatil bölgeleri) olarak dört ayrı başlıkta ele almıştır. Butik oteller ile ilgili olarak yapılan çalışmaların genellikle bir bölge özelinde ele alındıkları gözlenmektedir. Belirli standartların küresel ölçekte sağlanamaması nedeniyle özellikler ülkelere göre değişkenlik göstermektedir ve genel bir tanımlamaya sığdırılamamaktadır. Wheeler (2006) Understanding the Value of Boutique Hotels isimli çalışmasında öncelikle butik otel tanımlamalarını ele almış, farklı kişilerin yaptığı tanımlamaları değerlendirmiş ve 2001-2006 yılları arasında Amerika'nın Boston, New York ve Washington şehirlerindeki butik otellerin artışını ve ko- 
naklama fiyatlarını zincir oteller ile kıyaslamıştır. Lim ve Endean (2009) ise bu çalışmanın da amaçlarından biri olarak belirlenen butik otel tanımlamalarına açıklık getirmeyi hedeflemiştir. Estetik değerler ve işletme anlayışı olarak iki ayrı başlıkta, butik otel özelinde genel bir alanyazın taraması ile ele alınan çalışmada elde edilen bulgular İngiltere için değerlendirilerek yazar tarafından genel bir tanımlama getirilmiştir. Weaver (2009) ise turizm ve estetik tasarım kavramlarını birlikte ele almış estetik kaygılar üzerinden butik oteller ve zincir oteller arasında kıyaslamalara yer vermiştir. Yanı sıra günümüzde adı yeni duyulmaya başlayan tasarım otelleri design hotels, lifestyle oteller gibi yeni nesil butik otellere de değinmiştir. Design Hotels, HIP Hotels, Lifestyle Hotels gibi kavramlar konaklama yapıları ile ilgili olarak yazılmış birçok çalışmada yer bulmuş, fakat Pehlivanoğlu (2010) HIP Hotel (highly individual places/kendine özgü mekânlar) olarak tanımlanan "Konaklama Mekânlarının Kavramsal, Estetik ve İşlevsel Analizi" adlı çalışmasında yalnızca HIP Hotels kavramını ele almıştır.

Butik oteller hem farklı bir işletme anlayışı hem de farklı tasarımsal yaklaşımlara sahip olmak zorunda olduklarından bu konu ile ilgili yapılan çalışmalar turizm ve mimarlık ara kesitinde yer almaktadır. Turizm alanında yapılan çalışmalarda butik oteller; işletme prensipleri, müşteri memnuniyeti, personel nitelikleri, yıldızlı oteller üzerinden karşılaştırma gibi farklı konular üzerinden değerlendirilmiştir. Değişen yaşam şartları da turizm yapılarını şekillendiren bir etkendir ve butik oteller günümüzde kullanıcıların beklentilerine hizmet, konfor, tasarım gibi birçok yönü ile cevap vermektedir. Mimarlık alanında ise bu otellerin tasarımsal özellikleri açısından değerlendirmeler yapılmıştır. Can (2007) “Ürgüp'teki Geleneksel Konutların Butik Otel Olarak Kullanımının Değerlendirilmesi" adlı çalışmasında butik otel ve konut ara kesitinden, getirim sağlamak adına gerçekleştirilen dönüşümlerin kültürel varlık, turizm ve geleneksel dokuya olan olumlu ve olumsuz özelliklerini irdelemektedir. Çelik (2010)ise "Butik Otellerin Alaçatı Örnekleri Üzerine Analizi" isimli çalışmasında dönüştürülmüş ve yeniden inşa edilmiş butik oteller olarak ikiye ayırmaktadır ve yapısal özelliklerini karşılaştırmaktadır.

\section{YÖNTEM}

$\mathrm{Bu}$ araştırmanın alanyazındaki örnekler bağlamında alanındaki diğer çalışmalardan farkı, butik otel niteliklerine öncelikle butik kavramı üzerinden yaklaşılmasıdır. Araştırmada konaklama yapılarının türlerine ve süreçler içerisindeki değişimine de değinilecektir fakat asıl hedeflenen, butik anlayışının süreçlerdeki değişimi ve niteliklerinin okuyucuya aktarılmasıdır.

Araştırmada butik oteller ve yeni nesil otel yaklaşımları ile ilgili net standartların olmamasından kaynaklı problemler okuyucuya aktarılmaktadır. $\mathrm{Bu}$ otellerin resmi standartlara sahip olmayışı ve özel nitelikli konaklama yapıları sınıfına giren yapıların bu özellikleri barındırmaması nedeni ile kullanıcılar bu oteller hakkında doğru fikir sahibi olamamaktadır. Bu yaklaşım için istatistikî sonuçlar çıarmak kesin sonuç veremeyeceğinden anket yöntemleri uygulanmamıştır. Bu nedenle bugüne kadar bu alandaki yapılmış çalışmalar ve tanımlamalar araştırmadaki en önemli rolü oynamaktadır. Yetersiz tanımlamalara çözüm arayışı, alanyazında taramalar yapılarak geliştirilecektir. Yurtiçi ve yurtdışında bugüne kadar yapılmış çalışmalarda butik kavramına değinilmiş fakat yıldızlı otellerdeki gibi net standartların olmayışı butik otel yapılarında tutarsızlıklara neden olmuştur. Bu tutarsızlıklar ise butik kavramı üzerine farklı tanımlar yapılmasından kaynaklanmıştır. Farklı tanımları ortadan kaldırabilmek ise öncelikle butik yaklaşımını kelime anlamı üzerinden her yönü ile değerlendirmek ile daha sonra da bugüne kadar butik otel üzerine yapılmış tanımlamaların mevcut butik otel örnekleriyle kıyaslanmasıyla mümkün olacaktır. Yeni nesil otel yaklaşımları da (art hotels, design hotels, HIP hotels...) butik oteller ile çok benzer özellikler sergilediğinden bu otellerin sayısının artması ile daha büyük bir kavram karmaşasının ortaya çıkması kaçınılmazdır. Henüz Türkiye'de bu örnekler için bir adlandırma ve tanımlama yapılmamasından dolayı çalışmada daha çok yabancı kaynaklar ele alınmış ve sayılı tanımlamaları ve örnekleri değerlendirilerek yeni tanımlar getirilmiştir.

\section{DEĞiŞEN YAŞAM ŞARTLARI}

Çalışma butik otel özelinde, turizm ve mimarlık disiplinlerinin kesişim noktasında yer aldığından, değişen yaşam şartlarının hem butikleşme hem de seyahat anlayışının süreçler arası değişkenliği üze- 
rinden değerlendirilmesi gerekmektedir. Antik dönemden 19.yüzyıla kadar ticaret, kentler arası seyahatin en önemli nedenlerinden birini oluştururken alt ve orta gelir grubunda olan kişiler seyahat kavramına uzak kalmışlardır. Ulaşım sorunları nedeniyle daha çok zorunluluk doğrultusunda yapılan seyahatler, 19.yüzyılda Avrupa'da demiryollarının yaygınlaşması ile daha kolay, hızlı, ekonomik ve konforlu bir hale gelmiştir. Bu nedenle demiryollarının gelişimi seyahat olgusunda bir devrim olarak kabul edilmektedir. Demiryolları ile birlikte farklı ülkelere yapılan seyahatler artış göstererek kültür, sağlık, spor gibi amaçlar için de seyahatler yapılmaya başlanmıştır. Kayın'a (2000) göre, bu dönemde kara ulaşımı olarak demiryollarının, deniz ulaşımı olarak da buharlı gemilerin gelişmesi kervan ticaretinin gerilemesine sebep olmuştur ve daha uzun mesafelerde yapilan ticaret ile daha organize konaklama yapılarına ihtiyaç duyulmuştur ve bu dönemde modern konaklama anlayışı olarak oteller türemeye başlamıştır. Yüzyılın sonlarına yaklaşıldığında ise ikinci seyahat devrimi olarak nitelendirilen, havayolu kullanımının artışı da konaklama yapılarını değişkenliğe itmiştir. Ulaşımdaki kolaylık, turistik bölgelerin taşıma kapasitelerinin de kolaylıkla aşılmasına neden olmuş ve popüler olana talep çok kısa sürede artış göstererek, turistik bölgelerin yozlaşmasına yol açmıştır. Tatil köyü örneklerinde de kullanıcısına konaklama süresince bulunduğu bölgeyi tanımasını ya da dinlenmesini sağlamak yerine planladığı boş zamanlarını kurgulanmış bir sahnede geçirmesini sağlamıştır. Tanyeli'den (2004) aktaran Karasakaloğlu'nun (2011), kimliksiz, tarihsiz, toplumsal ilişkilerin kurulamadığı, sözleşmeli yok-mekân olarak nitelendirdiği tatil köyleri, bulundukları konuma, kültüre göre değil, otellerin markalarına göre şekillenmiştir ve daha fazla turist çekmek, farklı olmak adına, bir sahneye, lunaparka dönüştürülmekten çekinilmemiştir. Ülkenin ya da kentin coğrafi, kültürel özellikleri sergilenmemiş, bunun yerine görkemli, abartılı kimi zaman taklit yapılar ile pazarlama ve adını duyurma stratejisine gidilmiştir.Bu pazarlama tekniği ile müşterinin ilgisini çekilmiştir, fakat bu yaklaşımın ülkenin tanıtımına olan katkısının olumlu ya da olumsuz olduğu tartışılır bir durumdur.

Değişen yaşam şartları butikleşme üzerinden ele alındığında, butikleşmenin sanayi devriminden günümüze kadar farklı disiplinlerde etkisini gör- mek mümkündür. Moda, resim ve mimari, butikleşme etkilerinin görüldüğü alanlardan yalnızca bir kaçıdır. Butik kavramının kişiye özel olma durumu göz önünde bulundurulduğunda tüm süreçlerde kişiye özel hizmetin ve tasarımın önemli bir yeri olduğu bilinmektedir. Antik dönemden 19.yüzyıla kadar üretimde özel üretimin haricinde bir seçenek bulunmadığından herkes evinde kullandığı eşyadan, giydiği kıyafete kadar özel üretim ürünleri kullanmaktadır. Sanayi devrimi ile tüm dengeler değişerek makineleşme ve seri üretim insanların hayatına girmiş, gelişmiş ve hız kazanmıştır. Uzun'a (2011) göre sanayi devriminin sonrasında estetik beğeniler de değişkenlik göstermiştir. Sanayi devrimi ile birlikte üretim ve tüketimin anlam ve ilişkilerinin şekil değiştirmesine bağlı olarak "tüketim kültürü" ortaya çıkmıştır. Tüketilebilir olma yetisi yayıldıkça, nesnelerin birer statü göstergesi olarak çeşitlenmesi ve gösterge değerleri üzerinden eskimesi, tüketimin hız ve hacmini arttırıcı bir etken olduğundan, toplumun "ihtiyaçlar" yerine "istekler" yoluyla tüketime yönlendirilmesi, ekonominin yaşamsallığ 1 açısından en önemli araçlardan biri haline gelmiştir. Tüketimin kendine özgü kültürel kodlarıyla toplumsal değer kazanması ve bireyler arasında ortak bir alan oluşturması ile birlikte tüketim kültürünün varlığından söz edilmeye başlanmıştır.

Endüstrileşmenin beraberinde gelen seri üretim anlayışı ile kişiye özel tasarımlar, üretimler zorunluluk olmaktan çıkmıştır. Bunun sonucunda da yine yüksek gelire sahip kesimler özel üretimlerden ve özel tasarımlardan vazgeçmemişlerdir. Bu anlayış da farklı adlandırmalarla moda, resim, mimari gibi farklı disiplinlere dâhil olmuştur. 19.yy. sonundan İkinci Dünya Savaşı'na kadar olan süreçteki modern sanat akımlarının etkilerinin görüldüğü dönemde ortaya atılan moda tasarımı alanındaki en büyük yenilik, kişiye özel üretimi temel alan HauteCoutre anlayışı olarak kabul edilmektedir. Özüdoğru'nun da (2013) bahsettiği gibi bazı araştırmacilar HauteCoutre' un yanında sanayi devrimi ile ortaya çıkan ve 19. yy. son çeyreğinde giderek yaygınlaşan hazır giyim üretiminin de ayn öneme sahip olduğunu iddia etmektedirler. Her ne kadar hazır giyim sektörü rakip olarak gösterilse de farklı olmayı isteyen üst sınıf ekonomiye sahip insanlar HauteCoutre taleplerinden vazgeçmemişlerdir.

Endüstrileşme resim sanatında da etkisini göstermiştir. Geç 18.yy. ve erken 19.yüzyıla kadar bi- 
rinin portre sahibi olması onun üst sinıfta yer aldığını simgelerken, fotoğrafın icadı ile birlikte her sınıftan insan buna kolay yoldan sahip olabilmiştir. Sanat tarihçisi Ernst Gobrich de fotoğrafın icadı ile birlikte kendisine portresini yaptırmak isteyenlerin sayısının azaldığını belirtmektedir (Özüdoğru 2013: 214). İnsanlar kendi portrelerini özel olarak sanatçllara resmettirir iken fotoğraf makinesi ile birlikte bu yöndeki talep azalmıştır fakat halen daha bir ressamin eserine sahip olmak bir statü göstergesi olarak kabul edilmektedir. Sanayi devriminin etkileri, mimaride de görülmektedir. Yapı üretiminde ortaya yeni malzemelerin çıkması ile mimarlık büyük bir değişim sürecine girmiş, modern mimarlığın temelleri bu dönemde atılmıştır. Endüstrileşmenin beraberinde gelen süslemelerin, makine ile yapılması ve sonucundaki zevksiz ürünlerin ortaya çıkması sanatçı çevrelerinde ayaklanmaya sebep olmuştur ve bu dönemde (19. yy.) sanatçı ve eleştirmen John Ruskin ile ArtsandCrafts akımı ortaya çıkmış, William Morris ise bu akımın uygulamaya dökülmesinde önemli bir rol oynamıştır. Morris ortaçağ üretim geleneğini savunarak bu geleneği yaşatmak için 1861 yılında üretimleri el işçiliği ile yapılan duvar kâğıdı, mobilya, vitray, kitap, kumaş gibi ürünlerin tasarlandığı Morris and Company firmasını kurmuştur ve bu ürünler el işçiliği ile uzun zamanda, fazla emek sarf edilerek az sayıda üretildiği için yüksek fiyatlarla satılmıştır. Dolayısıyla ürünler, belirli bir sınıfa hitap ederek az sayıda tüketiciye ulaşmıştır. Teknolojinin de gelişmesi ile birlikte önemini giderek yitiren el işçiliği ve zanaatkârlığı yaşatma kaliteye ve iyiye yönelme çabası Art Nouveau ve Arts and Crafts akımlarının ortak gayesi olmuştur.

Üretimin hızlanması ile birlikte ürüne daha kolay erişim sağlanarak tüketimler de doğru orantılı olarak artış göstermektedir. Bunun sonucunda da daha keyfi harcamalar, daha farklı talepler türemektedir. Karasakaloğlu'na (2011) göre de günümüzde tüketimin ihtiyaçtan öte bir zevke dönüşmesi, insanların hiper-gerçek bir dünyaya ya da post-modern kültüre doğru yönelimi bize hız ve haz çağının yaşandığını hissettirmektedir. Yenidünya düzeni ile birlikte kişiler, yoğun tempolar1 sonucunda az zamanda, kaliteli ve özel hizmet taleplerinde bulunmakta, aynı zamanda da farklı deneyimler ile tatmin olmayı beklemektedir. 21 . yüzyıldaki bu yaşam biçimine konaklama ve eğ- lence sektöründeki en uygun yaklaşım butik anlayışıdır. Kısıtlı tatil süreçleri, yoğun iş temposu, evde geçirilen zamanının darlığı insanları hem deneyim arayışına itmektedir hem de ev konforunu dışarıda aramasına sebep olmaktadır. Çalışan, genç ve kültür seviyesi yüksek olan yeni nesilde ise bir dönemin popüler yapıları olan her şey dâhil sistemi ile hizmet veren tatil köylerine olan talep azalmaktadır ve farklı olanı yapılarda değil, daha çok o yapılarda sunulan deneyimlerde aramaktadırlar. Pehlivanoğlu'na (2011) göre; otel müşterisinin beklentileri artık sadece konaklama, dinlenme ve eğlence aktiviteleri olmamakta, aynı zamanda bulundukları yerel kültürü keşfetmek, sosyal aktivitelere katılmak, toplumsal bazı faaliyetlerin içine girmek gibi gereksinimlerinin de karşılanması gerekmektedir. Bu durum "Alternatif Turizm" kavramını da beraberine getirirken, büyük grup turlar geri planda kalmış, yerel ve kültürel özellikleri barındıran küçük ve orta ölçekli konaklama yapıları tercih edilmeye başlanmıştır. Alternatif turizm anlayışına cevap verebilecek konaklama yapısı olarak ise kişiye özel hizmeti esas alan ve sıcak samimi bir ortam yaratmayı, kullanıcısına evindeymiş gibi hissettirmeyi hedefleyen butik otel kavramı ortaya çıkmaktadır. Butik oteller de taleplerin artması ile birlikte kendi içlerinde niteliklerine göre sınıflandırılmalara sokularak, farklı adlandırmalar ile anılmaya başlamaktadır.

\section{BUTIK KAVRAMI}

Butik kelimesi anlam olarak, karmaşık veya özel müşteriye verilen hizmet kişiye özel olarak tanımlanmaktadır (Oxford Sözlüğü 2014). Bir diğer tanımda küçük, modaya uygun dükkân veya özel servis ya da ürünler sunan şirket olarak ele alınmaktadır (MerriamWebster Sözlügü 2014). Ayrıca genellikle özel, elit ürünlerin satıldığ ${ }_{1}$ küçük alışveriş dükkânı olarak belirtilmektedir. Bu tanımlara göre butik kelimesinde göze çarpan anahtar kelimeler küçük ve özel olan olarak belirlenebilmektedir. Küçük sıfatı ölçek ile ilgili olarak butiğin mekânsal tarafını belirtirken, özel olma durumu hizmet anlayışı ile özdeşleşebilmektedir. Mekânsal özellik olarak küçük olma durumunda dönemsel olarak bir farklılık gözlemlemek mümkün olmazken özel olma yaklaşımı son zamanlarda ortaya çıkmış bir olgu değildir. Butik anlayışı, 19. yüzyıldan beri var olmaktadır ve süreçler içinde farklı 
disiplinler üzerinden ele alınmıştır. Sanayi devrimi öncesine kadar birçok ürünün özel olarak, el işçiliği ile tasarlanması bir anlamda butik kavramını erken dönemlerde desteklemiştir. Kişiye özel hizmet, tasarım, küçük ölçekli mekânlar, el yapımı üretim, tek sayıda üretim ve sıra dışı deneyimler butik anlayışının bileşenlerini oluşturmaktadır. Tüm bu bileşenler bir konaklama yapısı olarak butik otel ile tek bir çatı altında toplandığında kişiye özel hizmet anlayışı ile müşterisine farklı deneyimler sunan mekânsal olarak zincir otel anlayışına zıt bir tavir sergilenmektedir.

Butik oteli tanımlamadan önce butik kavramına değinmek gerekmektedir. Dilimize Fransızcadan yerleşen butik kelimesi Türk Dil Kurumu'na (2014) göre; giyim ve süs eşyası satılan dükkân olarak tanımlanmaktadır. İnternet taramalarına göre ise butik yalnızca giyim eşyası satılan dükkân olarak değil küçük ölçekte, özel ve seçilmiş elit ürünlerin satıldığ 1 yer olarak belirtilmektedir. Aynı zamanda butik kelimesi özelleştirilen servis ve ürünler barındıran küçük, modaya uygun dükkân veya şirket olarak tanımlanabilmektedir. Tanımlara bakıld1ğında, küçük olma durumu ve özelleşmiş kelimelerinin ön planda olduğu görülmektedir. Bu tanımlardan yola çıkıldığında, butikliğin yani özel olma durumunun birçok alanda kendisine yer bulduğu söylenebilmektedir. Özünde butik olma durumu mekânsal, ürün odaklı ve hizmet anlayışı olarak değerlendirilebilir.

Butik kavramına mekânsal olarak yaklaşıld1ğında küçüklük kavramı ölçek olarak, özelleşmek kavramı da özgün tasarım olarak ele alınabilmektedir. Ölçek olarak küçük olması kullanım amaçlarına göre değişkenlik gösterse de mekânsal anlamda az sayıda kişi barındırması ortak noktadır. Özgün tasarım ise coğrafik konuma, bulunduğu kentin kimliğine, kullanıcı tiplerine göre değişkenlik gösterebilmektedir. Bu bağlamda, bulunduğu çevrenin özelliklerini yansıtması ve bunu yansıtırken de mekânsal özellikleri ile kullanıcısına kendisini özel hissettirmesi ortak nokta olabilir.

Mekânsal olmanın yanı sıra butik olma, yani özel olma durumu bir ürün üzerinden de sağlanabilmektedir. Özel tasarım bir sandalye kullanmak ya da bir tasarımcinın vazosunu kullanmak, sosyal statü simgesi olarak gösterilebilmektedir. Özel olarak üretilen ve eşi benzeri olmayan ürünler üst sınıflar için kendilerini özel hissetmeleri ve bunu başkalarına göstermek için önemli bir araç olmaktadır.

İşletme anlayışı olarak butik kavramı ele alınd1ğında müşterisini özel hissettirmek ilk hedeftir. Bu bağlamda hizmet verdiği personel sayısı ve personelin nitelikleri önemli rol oynamaktadır. Sadece bireysel hizmet verecek kapasitede personel yeterli olmamaktadır. Aynı zamanda personelin konusunda uzmanlaşmış olması da önem taşımaktadır (Bkz. Tablo 2).

Butik anlayışının tüm niteliklerini bir arada barındırması gereken butik oteller, genel yaklaşım olarak benzer özellikler gösterseler dahi bazı nitelikleri ülkelere göre değişkenlik gösterebilmektedir. Fiziksel özellikleri değişkenlik gösterse de hiz-

Tablo 2. Butik Kavramı

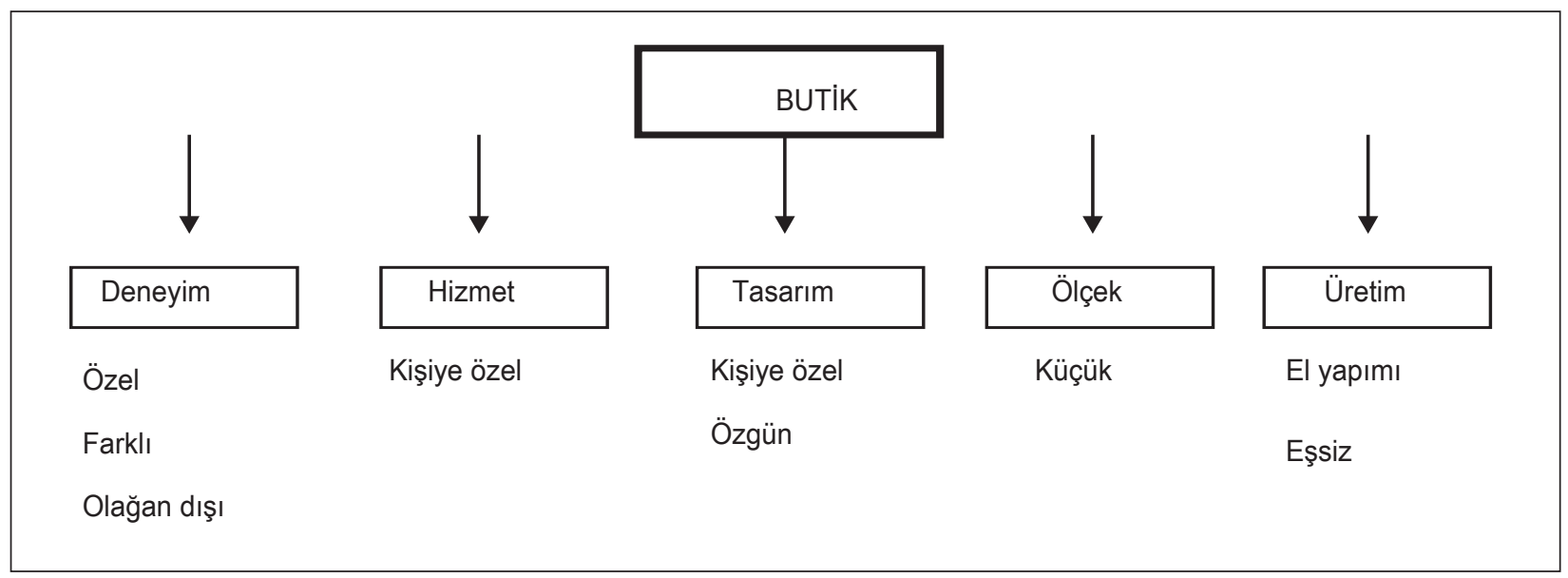

Kaynak: Aykol 2013. 
met anlayışları aynı kalmaktadır. Konumu ne olursa olsun butik otel kişiye özel hizmet sağlamalı, eşsiz, özgün tasarımlara sahip olmalı ve kullanıcısına farklı deneyimler sunabilmelidir. Farklı yazarlara göre butik otel tanımlamaları Geyik'in (2010) hazırladığ nebilmektedir (Bkz. Tablo 3).

Butik otel niteliklerinin net bir tanımlamaya sığdırılamaması farklı yazarların butik oteller ile ilgili söyledikleri yorumlarla da desteklenmektedir. Tabloda yazarların açıklamalarındaki ortak noktalar ve farklı noktalar tespit edilmeye çalışılmıştır. Tanımlamalardaki ortak noktayı butik otel birim- lerinin küçük olması ve eşsiz tasarıma sahip olma özelliği oluşturmaktadır. Yanı sıra otellerin oda sayısı her yazarda farklılık göstermektedir. Bir diğer ortak nokta "trend" ve "modern" tasarımlara sahip olması da eksik bir tanımlama olarak göze çarpmaktadır. Butik otellerde antika, klasik, retro gibi farklı tasarım anlayışlarına da yer verilebilmektedir. Önemli olan otelin bütünü ile bir tarz1nın olması ve özgünlügüüür.

Butik Otel Konaklama Derneği'ne (BoutiqueLodgingAssociations-BLLA) (2013) göre; butik otelde kültürel, tarihi veya otantik yaklaşımlar, bağımsız (zincir değil), ilgi çekici, kişiye

Tablo 3. Farklı Yazarlara Göre Butik Otel Tanımları

\begin{tabular}{|c|c|c|}
\hline Yazar & Yıl & Butik Otel Tanımlamaları \\
\hline Nobles ve Thompson & 2001 & $\begin{array}{l}\text { Butik otel en fazla } 100 \text { odalı olan, samimi ortama sahip, kişiye özel hizmetin bulunduğu, } \\
\text { personelin ve yönetimin tutumunun samimi olduğu, müşterinin neyi ne zaman } \\
\text { isteyeceğini bilen mükemmel hizmete sahip otellerdir. }\end{array}$ \\
\hline Albazzaz vd. & 2003 & $\begin{array}{l}20-55 \text { yaş arasındaki kişileri hedef pazar olarak belirleyen, mimari özellikleri ile sıcak } \\
\text { ve samimi bir ortam sunan otellerdir. }\end{array}$ \\
\hline Zengel & 2003 & $\begin{array}{l}\text { Küçük lüks otel tipolojisi ile bütünleştirilen butik oteller, niceliksel büyüklüğüne bağlı } \\
\text { olmayan, butik kelimesinin ifade ettiği üzere belirli bir bireysel tavır sergileyen, } \\
\text { dolayısıyla önceden belirlenmiş standartlarla sınırlandırılmayan bir yaklaşımdır. }\end{array}$ \\
\hline Forgsren ve Franchetti & 2004 & $\begin{array}{l}\text { Bu oteller ortalama } 86 \text { odalı, yüksek modern yapıya ve benzersiz kimliğe sahip olan } \\
\text { otellerdir. Otellerin odaları yüksek teknoloji çözümler ile çağdaş bir şekilde tasarlanmış } \\
\text { ve otellerin en çarpıcı özelliği servis kalitesinin yüksek ve gerçek müşteri ilişkilerine } \\
\text { sahip olmasıdır. }\end{array}$ \\
\hline Freund de Klumbis & 2004 & $\begin{array}{l}\text { 90’ı yıllardaki dönemlerde pazardan büyük paylar alan butik oteller, 50-100 odalı, } \\
\text { Avrupa ve Asya etkisinde mobilya tasarımları ile zincir olmayan işletmeler olarak tanımlanır. }\end{array}$ \\
\hline Victorino & 2005 & $\begin{array}{l}\text { Karakteristik özellikleri, çağdaş ve gerekli tasarımlar ile kişilere birçok yaşam tarzı } \\
\text { olanaklarını sunmasıdır. }\end{array}$ \\
\hline CatererSearch & 2005 & $\begin{array}{l}\text { Butik oteller özel tasarımlı ve } 50 \text { odadan az sayıda odası olan otellerdir. Genellikle } \\
\text { şehir merkezinde konumlanmasına rağmen, kırsal ve bölgesel yerlerde sayıları artmaktadır. }\end{array}$ \\
\hline Erkutlu ve Chafra & 2006 & $\begin{array}{l}\text { Tarz döşenmiş belli bir konsepte sahip, 3-100 arasında oda kapasitesi bulunan, telefon, } \\
\text { internet, klima, mini bar gibi teknolojik yeterlilikte ve müşterilerin görevlilere } 7-24 \\
\text { ulaşabilecekleri konaklama birimleridir. }\end{array}$ \\
\hline Aggett & 2007 & $\begin{array}{l}\text { Butik oteller maksimum } 100 \text { odalı, iç mekânlarında özel tasarım mobilyalara sahip, } \\
\text { özgün mekânlardır. }\end{array}$ \\
\hline Olga & 2009 & Butik otel iyi bir konsept ile tasarlanmış ve eşsiz bir atmosfere sahip olmalıdır. \\
\hline Lim ve Endean & 2009 & $\begin{array}{l}\text { Genellikle küçük ölçekli, } 100 \text { 'den az odaya sahip, zincir olmayan, genellikle şehir } \\
\text { merkezinde konumlanan, kişiye özel tasarıma ve hizmete sahip, 3, 4, } 5 \text { yıldızlı otel } \\
\text { standartlarındaki konaklama yapılarıdır. }\end{array}$ \\
\hline Henderson & 2011 & $\begin{array}{l}\text { Butik oteller maksimum } 100 \text { odalı olmalıdır. Bunun nedeni kişiye özel hizmeti } \\
\text { sağlayabilmeleridir. }\end{array}$ \\
\hline Balekjian ve Sarheim & 2001 & Trend, ilham verici, istek uyandıran ve çeşitli deneyimler sunan otellerdir. \\
\hline
\end{tabular}

Kaynak: Geyik 2010; Aykol 2013. 
Tablo 4. Turizm Tesislerinin Belgelendirilmesine ve Niteliklerine İlişkin Yönetmelik'in 43. Maddesine göre Butik Otellerin Barındırması Gereken Nitelikler

\begin{tabular}{ll}
\hline \multicolumn{1}{c}{ Türkiyede Butik Otellerin Barındırması Gereken Nitelikler } \\
\hline İç Dekorasyon & Modern, röprodüksiyon, antika özellikli mobilyalar, özgün tasarım \\
Birimler & Kapasiteye yeterli lobi ve oturma salonu, kapasitesi 50 kişiden az olmamak kaydı ile tesis yatak \\
& kapasitesinin en az \%75'ine alakart hizmeti veren asgari ikinci sınıf lokanta, yer alan ünitelerden en az \\
& birinin bulunması: 1) Kişi başına 1,2 metrekare alan düşecek şekilde en az 50 kişilik pasta salonu, \\
& 50 kişilik kabare, sinema, tiyatro etkinliklerinin yapıllabileceği salon veya en az 60 metrekare büyüklükte \\
& kütüphane ünitesi. 2) Açık veya kapalı yüzme havuzu 3) Jimnastik salonu, bowling-bilardo salonu, \\
& Türk hamamı, buhar banyosu, kar odası, tuz odası, tuzlu buhar odası, sıcak taş odası, alarm sistemi \\
& bulunan sauna, masaj üniteleri, cilt bakım üniteleri, spor sahası, tenis kortu, kayak pisti, duvar tenis salonu \\
\hline Konfor & Beş yıldızlı otel standartlarını taşıyacak şekilde düzenlenmeli \\
\hline Personel & Yatak kapasitesinin en az \%50'si oranında alanında eğitimli personel \\
\hline Hizmet & 24 saat oda servisi \\
& Çamaşır yıkama / kuru temizleme \\
& Günlük gazete servisi
\end{tabular}

Kaynak: 25852 Sayılı, 21.06.2005 Tarihli Resmi Gazete'de Yayımlanan “Turizm Tesislerinin Belgelendirilmesine ve Niteliklerine İlişkin Yönetmelik'in 43. Maddesi.

özel servis hizmeti, yüksek kalitede oda özellikleri, davetliler için oturma salonları, kütüphane gibi sosyal birimler olmalıdır. Türkiye'de ise Kültür ve Turizm Bakanlığı'nın yayınladığı Turizm Tesislerinin Belgelendirilmesine ve Niteliklerine İlişkin Yönetmeliğin 43. maddesine göre butik otellerin tanımı farklıdır. Butik otel; yapısal özelliği, mimarî tasarımı, dekorasyonu ve kullanılan malzemeleri yönünden özgünlük arz eden, işletme ve servis yönünden üstün standartlara sahip, deneyimli veya konusunda eğitimli personel ile kişiye özel hizmet veren, en az on, en fazla altmış odalı tesisler olarak belirtilmektedir(Bkz. Tablo 4).

Tablo 4'teki niteliklere göre, dekorasyon ile ilgili özellikler butik otel tanımlamaları için uygun iken birimlere getirilen sınırlamaların birçok butik otel örneğinde yerine getirilmediği gözlemlenmektedir. Personel ve konfor için belirtilen nitelikler açıklayıcı olurken hizmet anlayışı için verilen başliklar butik otel özelinde yetersiz kalmaktadır. 24 saat oda servisi, çamaşır yıkama, kuru temizleme ve günlük gazete servisi ortalama standartlardaki birçok otelde bulunmaktadır. Butik oteller kişiye özel hizmet anlayışı ile bu özelliklerin haricinde ekstra hizmetler barındırmalıdır.

Butik otellerde ölçek olarak küçüklük, az sayıda oda kapasitesi özellikleri belirtilmesine karşın net bir standart söylenememektedir. Oda kapasitesi ülkelere göre değişkenlik göstermektedir. Bunun haricinde kişiye özel hizmet anlayışı, farklı deneyimler sunma, tasarımda özgünlük gibi bir takım özellikler aynı kalmaktadır. Belirtilen nitelikler beș yıldızlı otellerdeki gibi keskin standartlara sahip olmadığı için daha yoruma dayanmaktadır ve değişik butik otel örneklerinde birbirlerine çelişen örnekler görmek mümkündür.

Kullanıcıların taleplerinin küçük ölçekli otellere doğru yönelmesinden sonra butik oteller de kendi içlerinde gruplaşmış, ortaya yeni otel kavramları atılmıştır. Bu gruplaşmalarda da yine oda sayısı az miktarda tutulmaktadır. Butik otelden farkları ise müşteriye akılda kalacak deneyimlerde sınırlar zorlanmakta ve müşteriye kendisini özel hissettirme anlayışı daha üst sınırlara çekilmektedir. Hizmet anlayışı ise esnek yemek saatleri, kişiye özel gazete hizmeti sınırlarının dışına çıkmış, müşterilere ismen hitap edilmesi, müşterinin havaalanından araba ile karşılanması ve otele gelir gelmez bavulundaki giysilerin ütülenmesine kadar taşınmıştır. Otelcilik sektöründeki bu yenilikçi atılımlar da yeni sınıflandırılmaya başlanmıştır. Bu sınıflandırmalar birbiri aralarında çok benzer özelliklere sahiptir. Sınıflandırılmaların yapılmasındaki en büyük neden ise arayıştır.

Otel kullanıcısının günden güne değişen talepleri, yaşam tarzı ile birlikte değişen, gelişen bek- 
lentiler ve onların farklı arayışları yeni sınıflandırılmaların doğmasında önemli rol oynamaktadır. $\mathrm{Bu}$ arayışların her birine cevap verecek yeni otel türleri gündeme gelmiştir. Bu yeni otel sınıflandırmaları henüz dünyanın her yerine tam anlamı ile yayılmamış fakat sayıları giderek artmaya başlamıştır. BLLA'e (Boutique Hotel Lodging Association) (2013) göre; butik otel tipolojileri 21 ayrı gruptan oluşmaktadır. Bunlar; Butik Otel (Boutique Hotel), Yaşam Tarzı Oteli (Lifestyle Hotel), Lüks Butik Otel (Luxury Boutique Hotel), Trend Otel (Trendy or Modern Hotels), Tasarım Otelleri (Design Hotels), Süit Oteller (All Suite Hotels), Mimari Oteller (Architectural Hotels), Artistik Oteller (Artistic Hotels), Avangart Oteller (Avant-Garde Hotels), Şehir Otelleri (City Hotels), Klasik Oteller (Classic Hotels), Klas Oteller (Classy Hotels), Konforlu Oteller (Comfortable Hotels), Konferans Oteli (Conference Hotel), Çağdaş Oteller (Contemporary Hotels), Kurumsal Oteller (Corporate Hotels), Sayfiye Otelleri (Country Hotels), Tasarımcı Otelleri (Designer Hotels), Özgün Oteller (Distinctive Hotels), Sıra Dışı Oteller (Extraordinary Hotels), Funky Hotels olarak adlandırılmaktadır. Ayrıca BLLA sinıflandırmasında yer almayan fakat Kültür ve Turizm Tesislerinin Belgelendirilmesine İlişkin Yönetmelik'te yer alan Özel Belgeli Tesislerin de bu grubun arasinda yer alması gerekmektedir. Tanımları ile birbirleri arasındaki benzerlikler ve yaygın olarak kullanılma durumu göz önünde bulundurulduğunda bu grupları Butik Oteller, Özel Belgeli Oteller, Yaşam Tarzı Otelleri, Trend veya Modern Oteller, Tasarım Otelleri, Artistik Oteller, Avangart Oteller, Klâs Oteller ve Sıra Dışı Oteller olarak dokuz başlık altında toplamak yeterli olacaktır.

Butik oteller (Boutique Hotel) BLLA tanımına göre; belirli müşterilere hizmet veren, samimi, genellikle lüks, ilginç ve üst kalite oteldir. Bu tanım, butik oteller için doğru fakat yetersiz bir tanım olarak kalmaktadır. Yatak kapasitesi, kişiye özel hizmet anlayışında mutlaka bulunması gereken özellikler, mekânsal olarak yer alması gereken birimler için detaylı bir tanımlama yer almamaktadır. Kültür ve Turizm Tesislerinin Belgelendirilmesine İlişkin Yönetmelik'in Özel Tesisler Başlıklı yedinci bölümünün 42. maddesinde yer alan Özel Belgeli Otellerde genel olarak butik oteller ile aynı özellikleri taşımaktadırlar. Bu tesisleri butik otellerden ayıran niteliklerden biri, Bakanlık tarafından desteklen- meleri ve Bakanlık onayı ile hizmete açılmalarıdır. Özel belgeli otellerin de butik otellerde olduğu gibi başlıca özellikleri özgün tasarıma ve üstün hizmete sahip olmalarıdır. Bunun yanı sıra bu tesisler, faaliyet gösterdikleri alanda ulusal veya uluslararası en az beş yıllık marka veya ün sahibi olması veya yerel, ulusal, başka uluslara ait kültürleri yansıtması özelliklerinden birine sahip olması gereklili$\breve{g} i$, bu tesisleri butik otellerden ayıran en belirgin niteliktir. Kültür ve Turizm Tesislerinin Belgelendirilmesine İlişkin Yönetmelik'te Özel Tesisler başlığı altında yer alan butik oteller ve aslında özel belgeli butik oteller olarak da anılan özel belgeli oteller karşılaştırılırsa mekânsal nitelikler ve hizmet nitelikleri açısından aynı tutumu sergiledikleri söylenebilmektedir. Butik otellerin sinıflandırılamayan, belirli kalıba sokulamayan kişiye özel hizmet anlayışları ve özgün tasarım nitelikleri henüz Türkiye'de turizm yönetmeliğinde belirli başlıklar altında toplanmasa da BLLA tarafından ayrı başlıklar altında ele alınmaktadır.

Butik otellerdeki deneyim yaklaşımının ön planda olduğu oteller için Yaşam Tarzı Otelleri (Lifestyle Hotels) başlığı kullanılmaktadır. Yaşam elemanlarını ve aktiviteleri, fonksiyonel tasarımları ile birleştiren müşterilerine keşfetme fırsatı tanıyan otel grubu olarak tanımlanmaktadır. Eşsiz tasarım niteliği ön planda tutulan butik oteller için ise Trend veya Modern Oteller(Trendy Hotels) tanımlaması uygun görülmüştür. Eşsiz tasarımlara sahip bu otellerde, modern teması ve yaşayan atmosfer baz alınarak tasarlanmış ultra lüks restoranları ve göze çarpan mekanları ile müşterisine çok özel deneyimler sunması hedeflenmiştir. Tasarım niteliği için yalnızca modern otel başlığı değil ayrıca Tasarım Oteli (Design Hotel) sınıflandırılması da kullanılmaktadır. Bu oteller, mimarisi ile ayırt edici özelliklere sahiptir ve her bir odasının tasarımında, yataktan mobilyaya kadar tüm ürünler titizlik ile seçilmiştir. Tasarım otelleri bireysel fakat çevresel faktörler göz ardı edilmeden tasarlanmıştır. Tasarım otelleri, onları tasarlayan kişilerin özel yetenekleri ile çeşitlilik göstermektedir. Artistik izlenimin, fonksiyonelliğin ve hayal gücünün bir arada harmanlanması ile başarılı bir tasarım oteli meydana gelmektedir. Müşterilerine konakladıkları süre boyunca yalnızca konfor değil, tasarımcısının yaratıcı bakış açısını yansıtıp huzurlu bir ortam sürekliliği sağlamaktadır. Özgün tasarımın dışında, butik otellerde bu- 
lunması gereken sanat eserlerinin yoğunlukta olduğu, kullanıcılarına sanat müzesi ortamı yaşatan oteller için ise Artistik Otel (Artistic Hotel) başlığ yer almaktadır. Artistik oteller en yüksek kalitede ve sanatsal çalışmaları bir arada barındıran konaklama alternatifi olarak gösterilmektedir. Artistik otellerin konaklayıcıları bir modern sanat müzesi ziyaretinin canlandırıcı ve neşelendirici hissiyatını yaşamaktadır. Bu özelleşmiş oteller artistik söylem ile yeniçağın konaklama mekânının karması olarak belirtilmektedir. Artistik otellerin bir örneği olarak gösterilen Avangart Otel (Avant - Garde Hotel) ise otel tasarımcılarının bu stil çerçevesinde bir otel odasından olan beklentilerinin sınırlarını aştıkları ve alışılagelmedik, ilginç, artistik, modaya uygun ve eşsiz olarak tasarımların bulunduğu oteller olarak tanımlanmaktadır. Butik otellerde genellikle yer alan lüks hizmet ve lüks objelerin yoğunlukta olduğu oteller Klâs Otel (ClassyHotels) olarak ayrı bir sinıflandırmada yer almaktadır. Klâs oteller rafine konaklama deneyimini yaşamak isteyen lüks yolcu kesimine hitap etmektedir. Müşteriler konaklamaları boyunca özel sanat eserlerini, ortamı yaşamayı ve en lüks servis kalitesini beklemektedir. Yalnızca deneyimin ön planda olduğu, farklı deneyim yaşamak adına kimi zaman konfordan bile ödün verilen oteller için Sıra Dışı Otel (Extraordinary Hotel) tanımı kullanılmaktadır. Bu oteller, yolcular için bir varış noktasıdır. Farklı deneyim konusunda bu otellerde limit yoktur. Buz ve diğer düşünülemeyen malzemelerden inşa edilmiş olabilir, yeraltında ya da bir ağacın üzerinde, okyanusun altında inşa edilmiş olabilir (Bkz. Tablo 5).

\section{BUTIK OTEL YAKLAŞIMI}

Butik otellerin ana bileşenleri olarak kişiye özel hizmet anlayışı ve farklı tasarım özellikleri göz önünde bulundurulduğunda, mimari, turizm, endüstriyel tasarım, halkla ilişkiler gibi birçok disiplin ile birlikte ele alınması gerekmektedir. Bu alanlardan yalnızca bir tanesinde bile bir eksiklik olması, butik otel niteliğinin kaybolmasına sebep olmaktadır. Butik otellerin en önemli özelliği ise kullanıcısına kendisini evindeymiş gibi hissettirmesidir. Bu durum kimi zaman otel odalarına evcil bir balık koyularak, kimi zaman ise personelin müşterilerine ismen hitap etmesi ile müşterilere ev ortamının s1caklığı ve rahatlığı hissettirilmiştir. Zengel'e (2003) göre de mekâna yönelik aidiyet duygularının en üst düzeyde hissettirilebildiği butik oteller, otel ile konutunun bir arakesitini oluşturan yapılar olarak da nitelendirilebilmektedir. Bu tür otel düzenlemelerinde ev ortamına yönelim gözlemlenirken yeni gelişen rezidans olarak tabir edilen konutlarda otel rahatlı̆̆ına değinilmektedir.

Günümüz konutlarında artık resepsiyonlar, oda hizmeti (housekeeping), ütü gibi otel hizmetleri eklenmeye başlamıştır. Hatta yüzme havuzu, spor salonu (fitness), sinema gibi sosyal aktivitelerin de konutların arasina eklemlenmesi otel ve konut kavramı arasındaki sınırı kaldırmıştır. Öyle ki artık rezidanslarda oturulan evler kişilerin seyahatleri süresince dilerler ise farklı kişilere mobilyaları ile birlikte kiralanabilir hale gelmiştir. Bu yaşam tarzında zaten 5 yıldizlı otel standartlarında konutlara sahip olan kişiler beş yıldızlı zincir otel yerine farklı nitelikleri barındıran butik otellere yönelmiş-

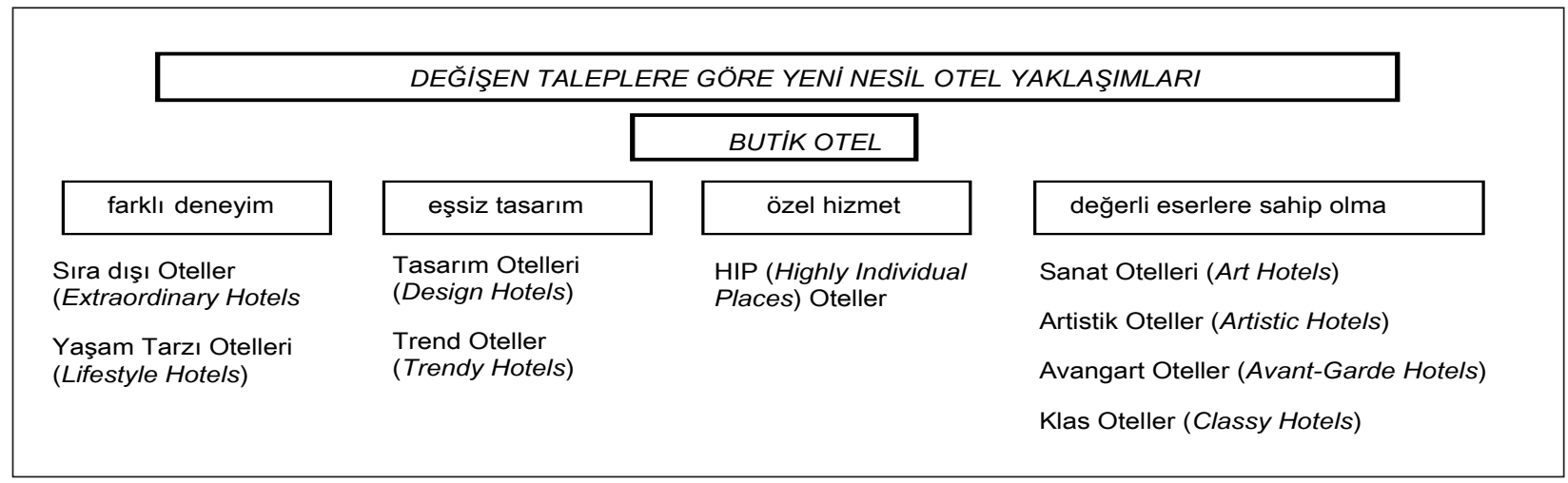

Kaynak: Aykol 2013. 
tir. Konut sisteminin ölçek olarak da büyümesi konutları otelleştirmiş, kullanıcı ev sıcaklığını ve ev ölçeğini butik otellerde aramaya başlamıştır. Sadece alış veriş merkezleri gibi kamusal mekânlar değil, konutlar da artık karma kullanımlı merkezler haline gelmiştir. Yüksek gelir grubunun simgesi haline gelen rezidanslarda spor salonları, yüzme havuzları, alışveriş merkezleri, sinema salonları gibi ekstra aktivite alanları türemektedir.

Günden güne otel ve konut kavramı iç içe girmeye başlamıştır. Konutlarda otel hizmeti arayışı artarken, otellerde de ev konforu aranmaktadır. Giderek otel ve konut arasındaki sinır yok olmaya başlamaktadır. Bu durumun en büyük etkeni artık konsept projelerin bina olarak değil de işletme ya da yaşam tarzı olarak satılmasıdır. "Plaza" ofisler, "kapalı site yerleşmeleri", "mall" çarşılar, "boutique" oteller bu duruma örnek olarak verilebilmektedir. Mekânsal kalite her dönemde kullanıcı için önemli bir faktör olurken, günümüzde mekânsal kalite bir zorunluluk haline gelmiş ve tek başına yetersiz kalmaya başlamıştır. Buna ek olarak yatırımcilar ultra lüks sitelerde kaliteli malzeme seçimleri ve şıklığın yanı sıra projelere bir yaşam tarzı eklemişlerdir. Rezidanslarda, sitelerde her türlü sosyal aktiviteye yer verilmiş, kısıtlı zamana sahip müşterisine hayatı kolaylaştıran bir alternatif olmuştur. Tüm bu hizmetlerin özünde yine ev konfo$\mathrm{ru}$, evindeymiş gibi hissetme anlayışı yatmaktadır. Kullanıcı hem kendi ev konforunu yaşamak, hem de beş yıldızlı otel hizmetini hem yaşadı ğı konutta hem de seyahat süresince konakladığı mekânda sürdürmek istemektedir. Butik oteller de bu durumda iyi bir alternatif haline gelmektedir. Buradaki çelişki beş yıldızlı otel kompleksleri standartlarına sahip konutlarda yaşayan kesimin ev konforu adı altında küçük ölçekteki konaklama yapısını tercih etmesidir. Değişen yaşam şartları aslında ev konforu anlayışını da etkilemektedir. Bu durumda büyük ölçekli karma kullanımlı yapılarda ev sıcaklığı hissiyatının verilmediğini söylemek yanlış olmayacaktır. Yanı sıra küçük ölçekte ev konforunu sunmayı hedefleyen butik otellerde deneyim söz konusu olduğunda, farklılıkta sinır tanınmamaktadır. Hapishane konseptli ya da okul konseptli bir butik otelde konaklamak müşterisine kendisini ne kadar evindeymiş gibi hissettirebilir? Bu durumda farklı deneyim sunmayı hedefleyen butik otellere ayrı bir sınıflandırma getirmek ara-kesitte çelişkileri minimuma indirecektir.
Bir diğer çelişki olarak butik otellerde zincirleşme ele alınabilir. Beş yıldızlı zincir otel konforuna sahip olan fakat niteliksel açıdan beş yıldızlı otellere nazaran daha fazla özen gerektiren butik oteller de giderek zincir otel olmaya başlamaktadır. $\mathrm{Bu}$ durum butik otelin tanımlamasına zıt bir yaklaşım olmasına rağmen zincir butik otellerin sayısı günden güne artmaya devam etmektedir. Zincir butik otellerin en bilinen örneği olarak W Otelleri gösterilebilir. Çoğu zaman beş yıldızlı otellerden daha yüksek ücretlerle hizmet veren butik otellerdeki lüks derecesi üst seviyededir. Farklı deneyimler sunmak söz konusu olduğunda ise butik otellerde deneyimi yaşatmak adına konfordan, teknolojiden uzak olan örneklerine rastlamak mümkündür. Elektrik kullanılmayan, dışarıdan deodorant, plastik gibi maddelerin içeriye sokulmasına izin verilmeyen veya yatak yerine tabut kullanılan fakat yine de yüksek ücretler karşılığında lüks ve konfor yerine deneyim satın alınan butik otel örnekleri kendilerine ait tanımlamalar ile çelişmektedir.

\section{SONUÇ VE DEĞERLENDIRME}

Butik oteller özel konaklama yapıları olarak değerlendirildiği için yıldızlı otellerdeki gibi belirli standartlara sahip değildir. Beş yıldızlı otel niteliklerinde olduğu gibi daha sayısal ve kesin ifadeler yoktur. Konfor, özel tasarım, özel hizmet, deneyim gibi daha genel nitelikleri barındırması gerekmektedir. Zaten eşsiz olma durumu, özel hizmet anlayışı gibi bileşenleri nedeni ile butik otellere net bir tanımlama getirmek mümkün olmayacaktır.

Hem ev gibi otel mantığını benimsemiş hem de hayalî deneyimler sağlama çabası çelişkinin en gözle görülür örneğini oluşturmaktadır. Tatil köylerinin sahte kimliklerine karşın özgün tasarımları ile ön planda olmayı hedeflemiş butik oteller, yine deneyim uğruna konaklama yapısını bir sahneye çevirmekten de geri kalmamaktadırlar. Baum'a (1996) göre de yaşam tarzındaki değişiklikler turizm ürünleri ve hizmet alanında daha yüksek kalite talep edilmeye başlanmıştır ve bireysel ilgi alanları, ihtiyaçlar göz önünde bulundurularak daha esnek programların beklentisi doğmaktadır. Bu esnek programların beraberinde net bir tanımı olmayan butik oteller kendi içlerinde giderek dağılacak, bu yapılar içinde çok büyük farklılıklar ortaya çıabilecektir. Butik oteller de çelişkileri devre dışı bırakmak adına kendi içlerinde sınıflandırılmaya 
başlanmaktadır. Bu yaklaşım ile giderek yaygınlaşan ve aynı oranda esnek tutumlar sergileyen butik oteller kendi içlerinde sinıflandırılarak müşterisinin özel ilgi alanına göre butik otelini seçmesinde yardımcı olacaktır. Bu bağlamda butik otel özelinde geliştirilecek çalışmaların yeni nesil otel tipolojilerine yönelmesi daha doğru olacaktır. Sınıfland1rılmalar tam olarak belirlenmedikçe butik oteller üzerindeki çelişkinin giderilmesi mümkün olmayacaktır. Esnek fakat birbiri ile çelişmeyen nitelikler belirlenmesi gerekmektedir. Günümüz yaşam şartlarına göre adaptasyon sağlayan yeni nesil otel yaklaşımları şüphesiz ki yeni sınıflandırmalar ile de desteklenecektir.

Genel olarak butik anlayışı tek bir başlık altında toparlanmaya çalışılmıştır. Bu çalışma ile bugüne kadar mekânsal özellikleri veya hizmet anlayışı ile ele alınmış olan butik otellerin kendi içerisindeki çelişkilerine dikkat çekilmeye çalışılmıştır. Butik otel tanımı ise mimarlık ve turizm başta olmak üzere farklı disiplinlerden farklı kişilerin bir araya gelmesi ile nitelikleri her yönüyle ele alınıp daha net bir başlık altında toplanmalı ve bir bilgilendirme kitapçığg yayınlanmalıdır. Günümüz yaşam tarzının iyi bir alternatifi olan butik otel, popülerliği firsat bilinerek getirim aracı olarak kullanılmaya çok müsait olduğundan bu durumun önüne geçmek için tanımlamaların netleştirilmesinin yanı sıra Turizm Bakanlığı tarafından yapılan belgelendirilmelerin ve bunun takibinin daha sıkı bir biçimde yapılması gerekmektedir. Bu çalışma ile otellerin denetlenmesi ve belgelendirilmesinde daha kesin ve tutarlı sonuçlar ortaya konabilecektir. Dolay1sıyla kullanıcılar da butik otelleri tercih ettiklerinde doğru izlenimlere sahip olacak ve pansiyondan bozma küçük ölçekli konaklama birimlerinde "butik" sıfatı ile maddi ve manevi olarak kandırılamayacaktır.

\section{KAYNAKÇA}

Aggett, M. (2007). What Has Influenced Growth in the UK's Boutique Hotel Sector?, International Journal of Contemporary Hospitality Management, 19 (2): 169-177.

Albazzaz, A., Birnbaum, B., Brachfeld, D., Danilov, D., Kets de Vries, O. ve Moed, J. (2003). Lifestyles of the Rich and Almost Famous: The Boutique Hotel Phenomenon in the United States, High Tech Enterpreneurship and Strategy Group Project, Insead Business School, Fontainebleau.

Altun-Doğaner, S. (2005). Turizm Mimarlığında Değiş̧im ve Temalı Oteller, Mimarist, 17: 60-67.
Anhar, L. (2008). The Definition of Boutique Hotels, HVS International, http://www.hospitalitynet.org/news/4010409.html, Erişim tarihi: 9 Mart 2014.

Aykol, E. (2013). "Butik Otellerde Mekân Çözümleri ve Tasarımsal Yaklaşımlar" Konulu, Architectural Seminar Workshop 2 Dersi için Hazırlanan Yayımlanmamış Çalışma Raporu. İzmir: Dokuz Eylül Üniversitesi Fen Bilimleri Enstitüsü.

Aytaç, Ö. (2006). Tüketimcilik ve Metalaşma Kıskacında Boş Zaman, Kocaeli Üniversitesi Sosyal Bilimler Enstitüsü Dergisi, 11 (1): 27-53.

Balekjikan, C. ve Sarheim, L. (2011). Boutique Hotel Segment: The Challenge of Standing out from the Crowd. HVS, http://www.hvs.com/Content/3171.pdf, Erişim tarihi: 9 Mart 2014.

Baum, T. (1996). Images of Tourism Past and Present, International Journal of Contemporary Hospitality Management, 8 (4): 25-30

Beneton, P. (1991). Toplumsal Sinuflar. İstanbul: İletişim Yayınları.

BLLA / Botique Hotel Lodging Association (2013). http://www. blla.org/lifestyle-hotels.htm, Erişim tarihi: 10 Aralık 2013.

Can, Ş. (2007). Ürgüp'teki Geleneksel Konutların 'Butik Otel' Olarak Kullanılmasının Değerlendirilmesi (Yayımlanmamış Yüksek Lisans Tezi). Ankara: Orta Doğu Teknik Üniversitesi Mimarlık ve Mühendislik Fakültesi.

Caterer Search (2005), "Market Snapshot: Boutique Hotels", Caterer\&Hotelkeeper, http://www.catererandhotelkeeper. co.uk/Articles/03.06.2005.300719/Market-snapshot-Boutiquehotels.html, Erişim tarihi: 9 Mart 2014.

Çelik, E. (2010). Butik Otellerin Alaçatı Örnekleri Üzerine Analizi (Yayımlanmamış Yüksek Lisans Tezi). Konya: Selçuk Üniversitesi Mimarlık ve Mühendislik Fakültesi.

Doğaner, S. (2013). Vitra Çă̆daş Mimarlık Dizisi 2 - Turizm ve Rekreasyon Yapıları. İstanbul: VÇMD.

Douglas, M. (1991). The Idea of a Home: A Kind of Space, Social Research, 58 (1): 287-307.

Elçin, N. (2007). Popüler Kültür-Mimarlık İlişkisinin Turizm Yapıları Üzerinde İncelenmesi (Yayımlanmamış Yüksek Lisans Tezi). İzmir: Dokuz Eylül Üniversitesi Fen Bilimleri Enstitüsü.

Erkutlu, H. ve Chafra, C. (2006). Relationship Between Leadership Power Bases and Job Stress of Subordinates: Example from Boutique Hotels, Management Research News, 29 (5): 285-297.

Freund de Klumbis, D. ve Munsters, W. (2004). Seeking the Ultimate Hotel Experience ESADE Escuela Universitaria de Turismo Sant Ignasi.

Forsgren, S. ve Franchetti. C. (2004). The Marketing Role of Unique Concepts for Hotels in Sweden (Yayımlanmamış Yüksek Lisans Tezi). Göteborg: Göteborg University Graduate Business School.

Geyik, S. (2010). Butik Otellerin Web Sayfalarının İçerik Analiziyle Değerlendirilmesi: Karşılaştırmalı Bir Araştırma (Yayımlanmamış Yüksek Lisans Tezi). Balıkesir: Sosyal Bilimler Enstitüsü.

Harvey, D. (1997). Postmodernliğin Durumu. Çev. S. Savran. İstanbul: Ayrintı Yayınları.

Henderson, J. C. (2011). Hip Heritage: The Boutique Hotel Business in Singapore, Tourism and Hospitality Research, (11): 217-223. 
http://www.newsweek.com/it-sure-isnt-motel-6-114323, Erişim tarihi: 11 Aralık 2013.

http://www.catererandhotelkeeper.co.uk/articles/25.5.2005.300719/ market-snapshot-boutique-hotels.htm, Erişim tarihi: 11 Aralik 2013.

İnceoğlu, M. ve İnceoğlu, N. (2013). Otel Tasarımında Yeni Eğilimler, Arredamento Mimarlık, 3: 61-71.

Karasakaloğlu, D. (2011). Bir Yok-Mekân Olarak Temalı Otellerde Yön Bulma ve Kaybolma Algılarının İncelenmesi: Antalya-Kundu Bölgesi Otel Örnekleri (Yayımlanmamış Yüksek Lisans Tezi). İzmir: Dokuz Eylül Üniversitesi Mimarlık ve Mühendislik Fakültesi.

Kayın, E. (2000). İzmir Oteller Tarihi. İzmir: İzmir Büyükşehir Belediyesi Kültür Yayını.

Lim, W. ve Endean, M.(2009). Elucidating the Aesthetic and Operational Characteristics of UK Boutique Hotels, International Journal of Contemporary Hospitality Management, 21 (1): 38-51.

McDonnel Covelli, J. (2005). Boutique Hotels are Getting New Interest, Business First of Buffalo, http://www.bizjournals. com/buffalo/stories/2005.01.31/focus4.html, Erişim tarihi: 9 Mart 2014.

Merriam Webster Sözlüğü (2014). http://www.merriam-webster. com/dictionary/boutique, Erişim tarihi: 8 Aralık 2012.

Nobles, H. ve Thompson, C (2001). What is a Boutique Hotel?, Hotel Online Special Report. http://www.hotel-online.com/ News/PR2001_4th/Oct01_BoutiqueAttributes.html, Erişim tarihi: 9 Mart 2014.

Olga, A. (2009). The Alternative Hotel Market, 16th International Conferance on Management Science and Engineering, Moskova, Rusya.

Özüdoğru, Ş. (2013). Modern Sanat Akımları ve Moda, İdil Dergisi (6): 211-235.

Paton, N. (2005). Market Snaphot: Boutique Hotels, http://www. catererandhotelkeeper.co.uk/Articles/03.06.2005.300719/Market-snapshot-Boutique-hotels.html, Erişim tarihi: 9 Mart 2014.
Pehlivanoğlu, B. (2011). HIP Hotels (Kendine Özgü Mekânlar / Highly individul Places) Olarak Tanımlanan Konaklama Mekânlarının Analizi, Tasarım + Kuram, 11-12: 83-97.

Rowe, M. (2003). Defining Boutique Chic, Lodging Hospitality, (13): 34-37.

Tanyeli, U. (2013). Oteller Dün, Bugün, Arredamento Mimarlık, 3: 60-61.

Tanyeli, U. (2004). Kitle Turizmi ve "Yok-Mekân” Mimarlığı, Arredamento Mimarlik, 7: 74-77.

Turizm Tesislerinin Belgelendirilmesine İlişkin Yönetmelik (2005). http://teftis.kulturturizm.gov.tr/TR,14518/turizmtesislerinin-belgelendirilmesine-ve-niteliklerin-.html, Erişim tarihi: 10 Aralık 2013.

Türk Dil Kurumu (2014). http://tdkterim.gov.tr/bts/, Erişim tarihi: 8 Aralik 2013

Uzun, İ. (2011). Prof. Dr Gürhan Tümer'e Armă̆an Mimarliğın Çevresinde / Mekânın İçinde Kuram, Eylem ve Söylem. İzmir: Mimarlar Odası İzmir Şubesi Yayınları.

Victorino, L., Verna, R., Plaschka, G. ve Dev, C. (2005). Service Innovation and Customer Choices in the Hospitality Industry, Managing Service Quality, 15 (6): 555-576.

Weaver, A. (2009). Tourism and Aesthetic Design: Enchantment, Style and Commerce, Journal of Tourism and Cultural Change, 7 (3): 179-189.

Wheeler, D. (2006). Understanding the Value of Boutique Hotels (Yayımlanmamış Yüksek Lisans Tezi) Massachusetts: Massachusetts Institute of Technology Department of Architecture.

Yenal, Z. (2013). Vitra Çă̆daş Mimarlık Dizisi 2 - Turizm ve Rekreasyon Yapıları. İstanbul: VÇMD.

Zengel, R. (2003). Yerel ile Küresel Arasında Butik Otel / Tatil Köyü İkilemi, Arredamento Mimarlık, 161 (9): 100-105

25852 Sayılı, 21.06.2005 Tarihli Resmi Gazete'de Yayımlanan "Turizm Tesislerinin Belgelendirilmesine ve Niteliklerine İlişkin Yönetmelik'in" 43. Maddesi. 